\title{
Students' Perceptions and Information-Sharing Patterns in Learning Authoring System Course through Blogging
}

\author{
https://doi.org/10.3991/ijet.v15i19.10950 \\ Nur Izzah Abdul Kadir \\ Sekolah Menengah Kebangsaan Bidor, Perak, Malaysia \\ syaheaz@yahoo.com \\ Zaidatun Tasir ${ }^{(凶)}$ \\ Universiti Teknologi Malaysia, Johor, Malaysia
}

\begin{abstract}
The use of blogs in teaching and learning has emerged as a useful educational technology resource. Hence, this study's main objective is to investigate the students' perceptions and information-sharing patterns in learning computer science education through blogging. Eighteen samples were chosen purposively in this study. The study collected both quantitative and qualitative data using questionnaires, semi-structured interviews, and students' blogs transcripts. The results revealed the positive outcomes of students' perceptions of blog aspects, such as writing, reading, and making comments. In terms of information-sharing patterns, student frequencies in writing and sharing information through blogging were high when they were given tasks or activities that would be evaluated by an instructor. This showed that instructors play an important role in motivating students to be actively involved in blogging. Rewards or marks also need to be given as an encouragement to students for them to continuously and actively use blogs for learning purposes.
\end{abstract}

Keywords-Perceptions of blogs, information-sharing pattern, educational blogging, Authoring System, reflective learning.

\section{Introduction}

Some computational courses are classified to be complex for many students [1], where complexity is defined as a problem that can have several solutions [2]. Some complex problems in computational courses involve learning programming [3]. For example, the Authoring System course exposes students to basic programming and authoring concepts. One of the more complex concepts in programming is the use of a scripting language such as Active Server Pages (ASP). ASP is used for creating websites, which a more difficult process than is frequently realised. This is because, when students are learning to code to develop a website or application (app), errors will often emerge that will require them to check, find the solution, and apply it accordingly [4]. However, sometimes, it is difficult to interpret the meaning of the error mes- 
sages prompted by the browser and, thus, students will get stuck on a problem that is difficult to unravel.

Thus, to ease the process of finding solutions for the possible errors that might emerge during the website development process, discussions, opinions, and reflections from others who are more knowledgeable are needed. One possible way for discussions to take place is through online discussion. As stated by Liaw and Waltonen et al $[5,6]$, the key benefit of online discussion is collaborative learning where, through this process, students can build knowledge and negotiate meaning by interacting with others. In addition, online discussions give students the time they need to process learning, write ideas and views, and reflect to increase the quality of learning $[7,8]$. Moreover, the act of writing (especially reflective writing) and discussion are an essential professional skill [9] within computer science education [10].

Blogs are one of the emerging online discussion technologies; they offer flexible and accessible opportunities for implementing collaborative and reflective writing and learning, either with instructors and/or peers $[8,11]$. In education, blogs have been used as a reflective learning tool, and the benefits of peer work and interdependence are increased by designing a learning environment that enables students to develop social, collaborative, communicative, and reflective skills [12]. Blogging can help students to become more media and information literate by helping them to clarify their choices about the content that they have written. Blogging also helps students to develop confidence, improve self-expression, and achieve a sense of fulfilment from publishing their work, since others can read those works [13]. Nevertheless, collaborative, communicative, and reflective activities have yet to gain as much attention in computer science education as they have in other disciplines, such as language education [8, 14], and few approaches such as blogging have been experimented with to support computer science education [14]. Therefore, blogging is a suitable pedagogical learning approach that can enable students to exchange ideas and share experiences, especially on the ASP topic, which requires many solutions and sources to overcome the problems that emerge. In addition, blogging also supports the social constructivist environment, where students can work together and support each other by sharing information and resources that are useful for their learning process and goals [15]. Furthermore, Purcel et al [16] also stated that it is important to research information-sharing patterns through blogging to better understand blogging pedagogy and perhaps its influence on learning analytics. Drawing from the advantages of blogging as relating to learning, this study has the following aims:

- Identifying students' perceptions regarding the educational benefits of writing a blog, reading other students' blogs, and reading students' comments

- Identifying students' perceptions of the blogging experience as an educational activity

- Identifying information-sharing patterns through blogging among students

To pursue these aims, the current study will gather relevant data via a mixed method of research design, which involved a combination of quantitative and qualitative data. For the quantitative measurement, the data were collected using a questionnaire. 
Regarding a qualitative measurement, semi-structured interviews, observations, and blog activity analysis have been used.

\section{$2 \quad$ Literature Review}

In this section, a few important points underpinning this study will be discussed in detail.

\subsection{Educational blogging and computer science education}

Since the research goal and pedagogical aspiration for most of the academic community is to improve learning effectiveness, universities and other higher education organisations are facing pressure to demonstrate the effectiveness of their educational efforts [17]. As educational approaches in 21st century learning is moving towards online learning, instructors need to be aware of how their students have progressed in their learning [18]. One of the approaches that can be implemented to address this learning need is by using online learning logs in which students can document their learning experiences and study understandings in a diary form [19]. As indicated in the literature $[17,20]$, blogging is beneficial for communication, instructional resources, collaborative activities, knowledge sharing, and social networking and for showcasing students' projects. This also means that blogging activities can benefit both instructors and/or students. The study conducted by Stiler et al [21] explored the use of blogs in pre-service education and noted that the depth and breadth of students' reflectivity were positively affected through blogging. By engaging in blogging activities, students are given opportunities to express their ideas to everyone [21]. Through this act, they can produce and share articles/assignments, and welcome comments and views from others [22]. Blogs can also serve as a means for the revision process by producing several versions of documents through the automatic archive and keyword-based search facility [22]. In addition, students' written messages in online learning tools can capture significant information about their critical thinking that should be analysed and understood for effective learning [23]. Hence, the use of blogs as an online learning tool has the potential to enhance learning's effectiveness more than traditional learning logs do. It is also found that blogs are useful online tools to help students to reflect, and it is through reflection that they can think back on the situations they have experienced to maximize their knowledge and understanding [24], thus publishing their ideas [25]. In addition, new ideas that are unique to other students can be developed in the knowledge construction and sense making process [26].

Despite the stated advantages, blogging activities are mostly applied in language education, and little attention has been paid to computer science education [8, 14]. Learning a computer science course like Authoring System requires the students to internalize theories learned through hands-on design activities [27]. It stresses the use of both a mental and a physical process, which comprises creative construction and dilemma handling as opposed to mere thinking [28, 29]. If this subject is learned in a 
typical way, students will probably encounter problems in making connections and engaging with meaningful learning. In addition, like any other area of computer science education, constant improvement in technology creates a need for experts to document the learning process, so they can learn on their own throughout their professional career [8].

Hence, an effective learning strategy is required to have a positive impact on students' learning process when values like skills in handling authoring tools are concerned. To pave the way, there is a need to integrate a blogging approach to support students' learning of hands-on skills effectively. Through this approach, the students are expected to share information knowledge and highlight the problems they encounter when designing the application to benefit others in the community. It is through this process that the individual's behaviour to transfer learned skills and knowledge can be assessed [27]. Previous research by Valtonen et al, Williams and Jacobs, and Yang [30, 31, 32] have also highlighted that the use of technology such as blogs is an important factor that drives the information-sharing process, and more needs to be done especially in uncovering the information-sharing patterns through blogging, as this can contribute towards a better understanding of blogging pedagogy and perhaps its influence on the approach to future learning analytics [16].

As little research has been done in the field of information sharing itself compared to the specific characteristics of sharing of knowledge [33] especially for computer science education, this study aims to make a contribution to students' viewpoints as well as their behaviour regarding their information-sharing approach. To be precise, it is expected to see what types of blogging posting (information, instructional, personal) and sharing (e.g., giving comments, contributing information, reflection) will be made and shared by the students during the learning process. By so doing, the students will perhaps no longer view their learning and experience in isolation but will use it as an opportunity for learning and constructing meaning with others and for encouraging lifelong learning [34].

\subsection{Blogging and social constructivist theory}

Social constructivism is an extended concept of cognitive constructivism, where it emphasises learning's social collaborative nature for cognitive development $[35,36]$. It was developed by the post-revolutionary Soviet psychologist Vygotsky. The crucial concept in social constructivism is the Zone of Proximal Development, which argues that with the help of more knowledgeable others, participants can master certain concepts or ideas that they would find difficult to learn on their own [37].

In a social constructivist learning environment, instructors need to create a studentcentred learning experience in which students are required to develop their own knowledge because it is believed that they can learn better when they discover concepts by interacting and collaborating among themselves rather than when they are given by the instructor. Several studies have also shown that collaborative learning results in better learning outcomes than individual oriented learning does [26]. Meanwhile, instructors might need to observe students; make them work in groups in exploring, thinking, and discovering knowledge; and guide them as they approach prob- 
lems or issues rather than directing them. In addition, instructors need to supply the students with encouragement and advice as they tackle the difficulties and challenges in solving the problems or issues.

It should be noted that the theoretical foundation of blogging activities in learning is actually derived from social constructivist learning. The research by [38] has provided a conceptual overview of how blogging fits with the social constructivist learning theory. Furthermore, a study conducted by [17] analysed blogs' content to further examine how blogs' performance reflects social constructivism in the learning process.

In this study, students were asked to address, explore, discover, and solve weekly issues related to the Authoring System course, write their own reflection, and review and comment on their peers' blogging contents. Instructors, meanwhile, merely supply the students with encouragement and advice as they tackle the difficulties and challenges in solving the problems or issues rather than directing them to the answer. In this way, social interaction and negotiation among peers as well as with the instructor were used to enact a social constructivist learning approach. The questioning and reasoning process during the blogging activities and reflections indirectly enables the assessment process to occur, and it should be noted that blogging activities and reflections are a form of alternative assessment tool [39, 40]. Social constructivist theories support the questioning and negotiation of meaning among peers [41].

\section{Methods}

\subsection{Research design}

This study used a mixed method of research design, which involved a combination of quantitative and qualitative data. For the quantitative measurement, the data were collected using a questionnaire, which was chosen because it could be used to gather information about subjects' beliefs, attitudes, behaviours, and demographic composition [42]. Regarding a qualitative measurement, semi-structured interviews, observations, and blog activity analysis have been used. The aim of using a qualitative measurement is to seek understanding of the context and how it explains individual/group behaviours [43].

This study involved the use of an instructor's and students' blogs. The Authoring System's instructor set up an instructor blog and made it known to the class by posting the address to the e-learning system. Each week, students were given an issue related to the Authoring System course, and they needed to solve the issue and write their comments to share their views on the given issue. Each student had their own blog in which they could add a post to each response. Students were also required to make reflections based on what they had learnt in that week in their own blog and to read and respond to peers' blog posts. Links to peers' blogs were listed in the instructor's blog. Through the semester, the instructor's and students' blogs were regularly monitored and reviewed to observe the activities that were taking place. The details of the duration and activities for data collection over 14 weeks are tabulated in Table 1. 
Table 1. Research Procedures

\begin{tabular}{|l|l|}
\hline \multicolumn{1}{|c|}{ Week } & \multicolumn{1}{c|}{ Activities } \\
\hline Week 1 & $\begin{array}{l}\text { Students were briefed on the class activities. } \\
\text { Students were instructed on how to create a blog and its purpose. }\end{array}$ \\
\hline Week 2 & $\begin{array}{l}\text { Students created their own blogs and shared the links. } \\
\text { Students familiarised themselves with the blog spaces. }\end{array}$ \\
\hline Week 3 & $\begin{array}{l}\text { Students started writing their blog entries. } \\
\text { The pilot study was conducted. }\end{array}$ \\
\hline Week $4-10$ & $\begin{array}{l}\text { The teaching and learning process continued as usual. } \\
\text { Students continued writing their blog entries. }\end{array}$ \\
\hline Week 11 & $\begin{array}{l}\text { Selected students were chosen for interviews. } \\
\text { The questionnaires were distributed. } \\
\text { Students continued writing their blog entries. }\end{array}$ \\
\hline Week 12 - 16 & $\begin{array}{l}\text { The teaching and learning process continued as usual. } \\
\text { Students continued writing their blog entries. }\end{array}$ \\
\hline
\end{tabular}

\subsection{Samples}

This study uses a purposive sampling, where, 18 graduate students enrolled in the Educational Technology programme will be selected. They were registered on an Authoring System course, which is also known as the Educational Technology programme's core course. This also means that this study's outcomes cannot be generalized to other groups; instead, the objective was to ascertain students' perception and information-sharing patterns in the learning Authoring System course through blogging.

\subsection{Instrumentations}

Data were collected through the questionnaires, analysis of blog activities, semistructured interviews, and observations. The questionnaire was designed to determine students' perceptions of blogging. In addition, the questionnaire also gives an insight into blogs' effectiveness from the participants' perspective. A 5-point Likert scale was used to help students make their choices. A Likert scale requires participants to respond to a series of statements by indicating whether they strongly agree (SA), agree (A), somewhat disagree (SWD), disagree (D), or strongly disagree (SD) [42]. The questionnaire's reliability index was 0.912 based on the Cronbach's alpha. This implies that the questionnaire was in the Excellent range [44] and was suitable to be used in the actual study. Meanwhile, for blog activities, content analysis was conducted to identify the information-sharing patterns in terms of types of posting and sharing.

\subsection{Data analysis}

The data from the questionnaires were analysed using descriptive statistics in the form of frequency, percentage, and mean. The mean scores' level was interpreted as follows: very low (1.0-1.80), low (1.81-2.60), moderate (2.61-3.40), high (3.41-4.20), 
and very high (4.21-5.0). Meanwhile, for the qualitative data, the analysis was based on the blogs' transcripts. The data were divided into four themes, which were (1) Number of posts per week, (2) Number of comments per week, (3) Types of posting, and (4) Types of sharing.

\section{$4 \quad$ Results and Discussions}

The results of students' perceptions about blogging are presented in Table 2.

Table 2. General perceptions about blogs

\begin{tabular}{|l|c|c|}
\hline \multicolumn{1}{|c|}{ Constructs } & Mean & Standard Deviation \\
\hline General knowledge about blogs & 3.87 & 0.77 \\
\hline $\begin{array}{l}\text { Perceptions regarding the educational benefits of writing a blog } \\
\text { Perceptions regarding the educational benefits of reading other stu- } \\
\text { dents' blogs and comments }\end{array}$ & 4.02 & 0.66 \\
\hline \multicolumn{2}{|c|}{ Experience of blogging: } & 0.64 \\
\hline Personal usage & 3.09 & 0.82 \\
\hline Communication usage & 4.13 & 0.66 \\
\hline Pedagogical usage & 4.02 & 0.68 \\
\hline Students' feelings about blogs & 4.07 & 0.72 \\
\hline
\end{tabular}

Table 2 shows that students possess high perceptions regarding the educational benefits of writing a blog and reading other students' blogs and comments. The same results can be found related to their feelings about blogs and experiences of blogging for communication and pedagogical purposes. Meanwhile, their general knowledge about blogs and experiences of blogging for personal purposes are also high despite the mean scores being lower than 4.00. Therefore, it can be concluded that the overall students' perceptions of blogging are positive.

Meanwhile, Table 3 presents the information-sharing patterns among the students. The posting types were categorised into three categories, namely, informational, instructional and personal. Informational posts are those that simply give information on the topic, which could be a definition post or a longer explanation of some aspects of the topic that the students were writing about. Meanwhile, instructional posts tell the users how to do something and can be specific tutorial or general 'how-to' articles. They can also contain step-by-step instructions and include pictures and videos. Instructional posts will educate the users [45], and these types of post can help users by telling them how to solve their problems. Personal posts refer to those containing information such as feelings.

As can be seen in Table 3, most of the students used blogs for personal purposes (26 posts), such as posting about their feelings. For instructional posts, most students wrote reflections using the step-by-step instructions on how to solve problems in the practical test. The informational posts written by the students were more about sharing knowledge and information about the ASP topic. 
Table 3. Information-Sharing Patterns

\begin{tabular}{|c|c|c|c|c|c|c|c|c|}
\hline \multirow{3}{*}{ Blogger } & \multirow{3}{*}{$\begin{array}{c}\text { Post } \\
\text { (n) }\end{array}$} & \multirow{3}{*}{$\underset{\text { (n) }}{\text { Comment }}$} & \multicolumn{3}{|c|}{ Types of Post } & \multicolumn{3}{|c|}{ Types of Sharing } \\
\hline & & & \multirow{2}{*}{\begin{tabular}{|c|} 
Informational \\
$(n)$ \\
\end{tabular}} & \multirow{2}{*}{\begin{tabular}{|c|} 
Instructional \\
$(n)$ \\
\end{tabular}} & \multirow{2}{*}{\begin{tabular}{|c|} 
Personal \\
$(n)$
\end{tabular}} & \multirow{2}{*}{$\begin{array}{c}\text { Give } \\
\text { Comments }\end{array}$} & \multirow{2}{*}{\begin{tabular}{|l|} 
Contribute \\
Information \\
\end{tabular}} & \multirow{2}{*}{$\begin{array}{c}\begin{array}{c}\text { Reflection } \\
\text { on }\end{array} \\
\text { Activity } \\
\end{array}$} \\
\hline & & & & & & & & \\
\hline $\mathrm{B} 1$ & 3 & 2 & - & 1 & 2 & 1 & - & 1 \\
\hline $\mathrm{B} 2$ & 0 & 0 & - & - & - & - & - & - \\
\hline B3 & 2 & 0 & - & 2 & - & - & 1 & - \\
\hline B4 & 2 & 1 & - & 1 & 1 & 1 & - & 1 \\
\hline B5 & 2 & 1 & - & - & 2 & - & - & - \\
\hline B6 & 5 & 10 & - & 3 & 2 & 1 & 1 & 1 \\
\hline B7 & 9 & 18 & - & 6 & 3 & 1 & I & 1 \\
\hline B8 & 3 & 19 & - & 2 & 1 & I & I & I \\
\hline B9 & 4 & 6 & - & 1 & 3 & 1 & - & 1 \\
\hline B10 & 1 & 2 & - & - & 1 & 1 & - & - \\
\hline B11 & 1 & 1 & - & 1 & - & 1 & - & 1 \\
\hline B12 & 4 & 6 & 2 & 1 & 1 & 1 & 1 & 1 \\
\hline B13 & 1 & 3 & - & - & 1 & 1 & - & 1 \\
\hline B14 & 3 & 1 & 1 & 1 & 1 & 1 & 1 & 1 \\
\hline B15 & 4 & 1 & - & - & 4 & 1 & - & - \\
\hline B16 & 3 & 2 & - & 1 & 2 & 1 & - & 1 \\
\hline B17 & 2 & 2 & - & 1 & 1 & 1 & - & 1 \\
\hline B18 & 2 & 3 & - & 1 & 1 & 1 & - & 1 \\
\hline \begin{tabular}{|l|} 
Tutor \\
\end{tabular} & 18 & 57 & 6 & 7 & 5 & NA & NA & NA \\
\hline
\end{tabular}

*B=Blogger, $\mathrm{NA}=$ Not applicable

The study also revealed that in terms of the types of sharing, the majority of the students shared by providing comments and reflection on activities, while only six students shared by contributing information. Less contribution on sharing information led to little new knowledge and ideas creation. Through observations and interviews, it was found that students keen on sharing their reflections on the provided activity rather than sharing information because (i) marks were given, and (ii) it is easier for them to share the step-by-step process rather than dedicate their energies to giving critical thought on the issues/problems that they are required to solve. On a positive note, it can be said that rewards play an important role in encouraging students in blogging activities.

Figure 1 shows the weekly correlation between the instructor's and the students' posts and comments. Students started writing posts when the instructor wrote a post. This was illustrated in week 1 , when the instructor wrote 5 posts and the students wrote 11 posts. The numbers of posts were perhaps high because the students were excited about sharing information, as this was their first experience of having a blog, and they wanted to share more information. In addition, it might be due to the easy-touse services in blogs, such as comment facilities, as they are easy to update and the blog entries can consist of texts, images, hyperlinks, and audio and video elements. This is aligned with the findings from the questionnaire, where students agreed that blogs provide excellent facilities for users. The features and facilities provided made the students feel that their studies were more enjoyable when they were blogging. 


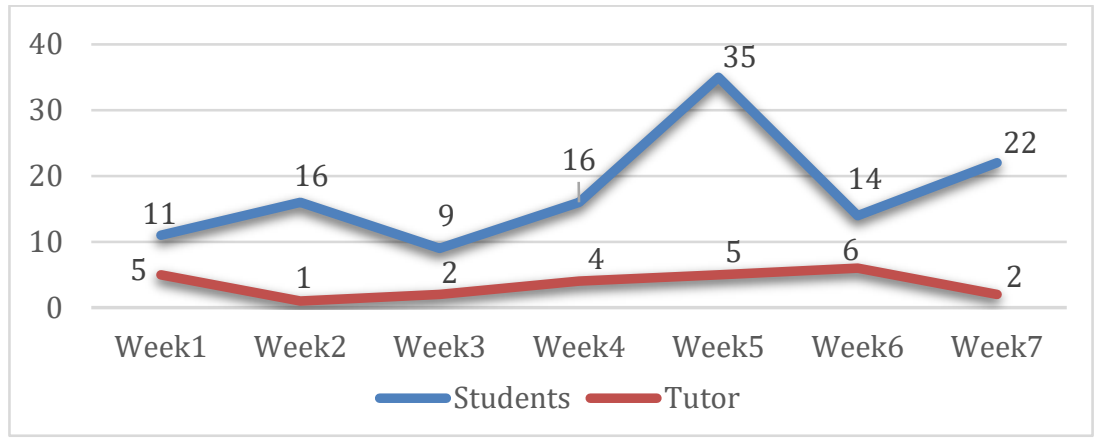

Fig. 1. Numbers of blog posts and comments per week

However, although the numbers of the instructor's posts and comments were reduced in the second week, there was no corresponding reduction in the number of students' posts and comments. The instructor was purposely not posting many posts in that particular week, as she wanted to see the students' reactions and behaviour. Their response was encouraging, as the students continued to create posts and make comments. In addition, the numbers of students' posts increased in week 4 and week 5 , which was due to the instructor having put some hints and information related to their practical test. Thus, they were using their blogs in the best possible way by sharing information that was related to the practical test. In week 7, the numbers of posts increased again from week 6 . This was because students needed to reflect based on the activity given in their blog and due to the marks given. Generally, students will use the blog actively when they are given rewards, such as marks. As stated by [46], rewards can have the most meaningful impact on how to improve the bloggers' intentions and their conduct in operating their blogs.

\section{Conclusion}

The findings showed that the students used the blogs more for communication purposes, followed by pedagogical purposes, and personal purposes. In terms of communication purposes, the students used the blogs to get information from others' blogs. In addition, they could also express their feelings in their blogs, which made them enjoy the blogging activities. In terms of the information-sharing patterns, the overall findings showed that most of the students used blogs frequently to write personal information, such as feelings about the learning process, as well as instructional posts. Little attention that was paid to contributing more information during the learning process, which certainly warrants further investigation to understand and identify the significant causes. In addition, it is suggested that future research could investigate the application of gamification techniques and components (e.g., badge, leaderboard, virtual good etc) in blogging activities to attract students' attention and, most importantly, their engagement. The provision of marks alone is not enough to facilitate 
encouraging contributions on information and in revealing individual behaviour, values, attitudes, and motivators towards learning computer science education courses.

\section{Acknowledgement}

The authors would like to thank the Universiti Teknologi Malaysia (UTM) and Ministry of Higher Education (MoHE) Malaysia for their support in making this project possible. This work was supported by the Research University Grant [Q.J130000.2410.04G79] initiated by UTM and MoHE.

\section{$7 \quad$ References}

[1] Hartmanis, J., \& Hopcroft, J. (1971). An Overview of the Theory of Computational Complexity. Journal of Association for Computing Machinery, 18(3), 444-475.

[2] Rodriguez, J. (2000). CEPADE, Universidad Politécnica de Madrid /IDOE Univ. Alcalá de Henares.

[3] Wiedenbeck, S., LaBelle, D. \& Kain, V. N. R (2004, April). Factors Affecting Course Outcomes in Introductory Programming. In Proceedings of the 16th workshop of the psychology of programming interest group (pp. 97-110). doi=10.1.1.103.9447

[4] Reynolds, J. (2008). Some thoughts on teaching programming and programming languages. SIGPLAN Notices, 43(11), 108-110. https://doi.org/10.1145/1480828.1480852

[5] Liaw, S. (1999). Enhancing interactivity into web-based learning environment. Retrieved from https://eric.ed.gov/?id=ED447785

[6] Waltonen-Moore, S., Stuart, D., Newton, E., Oswald, R., \& Varonis, E. (2006). From virtual strangers to a cohesive learning community: The evolution of online group development in a professional development course. Journal of Technology and Teacher Education, 14(2), 287-311. https://www.learntechlib.org/p/5686/

[7] Afify, M. K. (2019). The influence of group size in the asynchronous online discussions on the development of critical thinking skills, and on improving students' performance in online discussion forum. International Journal of Emerging Technologies in Learning, 14(5), 132-152. https://doi.org/10.3991/ijet.v14i05.9351

[8] Demmans Epp, C., Akcayir, G., \& Phirangee, K. (2019). Think twice: exploring the effect of reflective practices with peer review on reflective writing and writing quality in computer-science education. Reflective Practice, 20(4), 533-547. https://doi.org/10.1080/ 14623943.2019 .1642189

[9] Anewalt, K. (2003). A professional practice component in writing: A simple way to enhance an existing course. Journal of Computing Sciences in Colleges, 18(3), 155-165. Retrieved from https://dl.acm.org/citation.cfm?id=771733

[10] Hoffman, M. E., Dansdill, T., \& Herscovici, D. S. (2006). Bridging writing to learn and writing in the discipline in computer science education. SIGCSE Bulletin, 38(1), 117-121. https://doi.org/10.1145/1124706.1121379

[11] Glogoff, S. (2005). Instructional blogging: promoting interactivity, student-centered learning, and peer input. Innovate. Journal of Online Education, 1(5). Retrieved from https://www.learntechlib.org/p/107281/ 
[12] Luca, J., \& McLoughlin, C. (2005). Can blogs promote fair and equitable teamwork? Proceedings of ASCILITE 2005: Balance, Fidelity, Mobility: maintaining the momentum? (pp. 379-385). Retrieved from http://www.ascilite.org/conferences /brisbane05/blogs/proceedings/45_Luca.pdf

[13] Windham, C. (2007). Reflecting, writing and responding: reasons students blog. EDUCAUSE Learning Initiative, 2(2009), 129-144. Retrieved from http://kkermode.com /ctl/BLOGGING/why_students_blog_10p.pdf

[14] Mohamad, S. K., Tasir, Z., Harun, J., \& Shukor, A. (2013). Pattern of reflection in learning authoring system through blogging. Computers \& Education, 69, 356-368. https://doi.org/10.1016/j.compedu.2013.07.031

[15] Wilson, B. G. (1996). Constructivist Learning Environments: Case Studies in Instructional Design. Educational Technology Publication, Englewood Cliffs NJ

[16] Purcel, B. K., \& Xie, H. (2014). Patterns and pedagogy: Exploring student blog use in higher education. Contemporary educational technology, 5(2), 96-109. Retrieved from https://dergipark.org.tr/en/download/article-file/252222. https://doi.org/10.30935/cedtech/6118

[17] Du, H. S., \& Wagner, C. (2007). Learning with weblogs: Enhancing cognitive and social knowledge construction. IEEE Transactions on Professional Communication, 50(1), 1-16. https://doi.org/10.1109/tpc.2006.890848

[18] Felder, R.M. and Brent, R. (1996). Navigating the bumpy road to student centered instruction. College Teaching, 44(2), 43-47. https://doi.org/10.1080/87567555.1996.9933425

[19] Baker, J. H. (2003). Teaching tip: The learning log. Journal Information System Education, 14(1), 11-14. Retrieved from https://search.proquest.com/openview /211da8d14e9634b18af867699d6285ae/1?cbl=25848\&pq-origsite=gscholar

[20] Ray, J. (2006). Welcome to the blogosphere: The educational use of blogs (aka edublogs). Kappa delta pi record, 42(4), 175-177. https://doi.org/10.1080 /00228958.2006.10518024

[21] Stiler, G. M., \& Philleo, T. (2003). Blogging and blogspots: an alternative format for encouraging reflective practice among preservice teachers. Academic Research Library, 123(4), 789-798. Retrieved from http://search.ebscohost.com/login.aspx ?direct $=$ true $\& \mathrm{db}=\mathrm{a} 9 \mathrm{~h} \& \mathrm{AN}=10187536 \&$ site $=$ ehost-live

[22] Fessakis, G., Tatsis, K., \& Dimitracopoulou, A. (2008). Supporting "learning by design" activities using group blogs. Journal of Educational Technology \& Society, 11(4), 199212. Retrieved from https://www.jstor.org/stable/jeductechsoci.11.4.199

[23] Hayati, H., Chanaa, A., Idrissi, M. K., \& Bennani, S. (2019). Doc2Vec \& Naïve Bayes: learners' cognitive presence assessment through asynchronous online discussion TQ transcripts. International Journal of Emerging Technologies in Learning, 14(8), 70-81. https://doi.org/10.3991/ijet.v14i08.9964

[24] Schon, D. A. (1991). The Reflective Practitioner: How professionals think in action, England, Ashgate Schon, https://doi.org/10.4324/9781315237473

[25] Stavroulia, K-E \& Lanitis, A. (2019). Enhancing reflection and empathy skills via using a virtual reality-based learning framework. International Journal of Emerging Technologies in Learning, 14(7), 18-36. https://doi.org/10.3991/ijet.v14i07.9946

[26] Nardi, B. A., Schiano, D. J., Gumbrecht, M. \& Swartz, L. (2004). Why we blog. Common of the ACM, 47(12), 41-46. https://doi.org/10.1145/1035134.1035163 
[27] Wang, S. K. (2006). Learning Hands-On Skills in an Online Environment: The Effectiveness of Streaming Demonstration Animation. Journal of Interactive Online Learning. 5(1), 1-14. Retrieved from http://www.ncolr.org/jiol/issues/pdf/5.1.1.pdf

[28] Fischer, G., Lemke, A. C., Mastaglio, T., \& Morch, A. I. (1991). Critics: An Emerging Approach to Knowledge-Based Human-Computer Interaction. International Journal of Man-Machine Studies. 35(5), 695-721. https://doi.org/10.1016/s0020-7373(05)80184-1

[29] Saether, K. (2006). End-User Development with Design Environments: Gradual Mastery of Programming. Master Thesis. Retrieved from https://www.duo.uio.no hhandle/10852/9525.

[30] Valtonen, T., Havu-Nuutinen, S., Dillon, P. \& Vesisenaho M. (2011). Facilitating collaboration in lecture-based learning through shared notes using wireless technologies. J. Com. Assis. Lear., 27(6), 575-86. https://doi.org/10.1111/j.1365-2729.2011.00420.x

[31] Williams, J.B. \& Jacobs, J. (2004) Exploring the use of blogs as learning spaces in the higher education sector. Australasian J. Educ. Tech., 20(2), 232-47. https://doi.org /10.14742/ajet.1361

[32] Yang, S. H. (2009). Using blogs to enhance critical reflection and community of practice. Edu. Tech. Society, 12(2), 11-21. https://www.jstor.org/stable/jeductechsoci.12.2.11

[33] Islam, S., Nowrin, S., \& Mostofa, S. M. (2017). Knowledge Sharing Pattern Among the Arts Faculty Students of Dhaka University: A Survey. DESIDOC Journal of Library \& Information Technology, 37(4), 243-248. https://doi.org/10.14429/djlit.37.4.9952

[34] Bharuthram, S. (2018). Reflecting on the process of teaching reflection in higher education. Reflective Practice, 1-12. https://doi.org/10.1080/14623943.2018.1539655

[35] Derry, S. J. (1999). A fish called peer learning: Searching for common themes. Cognitive perspectives on peer learning, 9(1), 197-211. Retrieved from https://www.taylorfrancis.com/books/9781410603715 /chapters/10.4324/9781410603715-15. https://doi.org/10.4324/9781410603715

[36] Vygotsky, L. S. (1978). Mind in society: The development of higher psychological processes. Cambridge: Harvard University Press

[37] Martin, J. 1992. "Cognitive-mediational research on counseling and psychotherapy". In Psychotherapy process research, Toukmanian, S. G. and Rennie, D. L (Eds). 108-133. Newbury Park, CA: Sage. Retrieved from https://psycnet.apa.org/record/1992-98068-005

[38] Ferdig, R. E., \& Trammell, K. D. (2004). Content delivery in the 'blogosphere. The Journal Online: Technological Horizons in Education, 2, 1-8. Retrieved from https://www.learntechlib.org/p/77152/.

[39] YuekMing, H., \& Manaf, L. A. (2014). Assessing learning outcomes through students' reflective thinking. Procedia - Social and Behavioral Sciences, 152, 973-977. https://doi.org/10.1016/j.sbspro.2014.09.352

[40] Janisch, C., Liu, X., \& Akrofi, A. (2007). Implementing alternative assessment: Opportunities and obstacles. The Educational Forum, 71(3), 221-230. https://doi.org/10.1080 $\underline{100131720709335007}$

[41] Fosnot, C. T. (2005). Constructivism: Theory, perspectives and practice (2nd ed.). New York, NY: Teacher's College Press.

[42] Gay, L. R., Mills, G. E., \& Airasian, P. (2009). Educational research: Competencies for analysis and applications. United States: Pearson Educational International 
[43] Hoepfl, M. C. (1997). Choosing qualitative research: a primer for technology education researchers. Journal of Technology Education, 9(1), 47-63. Retrieved from https://files.eric.ed.gov/fulltext/EJ553339.pdf

[44] George, D., \& Mallery, P. (2003). SPSS for Windows Step by Step: A Simple Guide and Reference. Boston: Allyn \& Bacon. https://doi.org/10.4324/9781351033909

[45] Park, G. (2008). All 13 Types of Blog: Which Ones Are You Missing? Retrieved from http://www.winningtheweb.com/13-types-blog-posts.php

[46] Liu, S. H., Liao, H. L., \& Zeng, Y. T. (2007). Why people blog: an expectancy theory analysis. Issues in Information Systems, 8(2), 232-237. Retrieved from http://iacis.org/iis/2007/Liu_Liao_Zeng.pdf

\section{Authors}

Nur Izzah Abdul Kadir is a teacher at Sekolah Menengah Kebangsaan Bidor, Malaysia.

Zaidatun Tasir is a lecturer at School of Education, Faculty of Social Sciences and Humanities, Universiti Teknologi Malaysia. p-zaida@utm.my

Article submitted 2019-05-29. Resubmitted 2020-06-25. Final acceptance 2020-06-25. Final version published as submitted by the authors. 